\title{
LANGUAGES FOR SPECIFIC PURPOSES AND DYNAMICS OF NATIONAL IDENTITY
}

\author{
Povilas Aleksandravičius, Liudmila Mockienė, \\ Sigita Rackevičienè, Lora Tamošiūnienè \\ Institute of Humanities, Mykolas Romeris University, Vilnius, Lithuania \\ E-mail: ${ }^{1}$ povilasal@mruni.eu; ${ }^{2}$ liudmila@mruni.eu; ${ }^{3}$ sigita.rackeviciene@mruni.eu; ${ }^{4}$ lora@mruni.eu
}

\begin{abstract}
Creating and using language for special purposes reflects a rather high level of human needs in the hierarchy proposed by an American psychologist A. Maslow through creative activities and self-actualisation. The understanding of one's own belonging and identity as a manner of self-actualisation may happen through specific language usage. The article focuses on the review of the emerging European identity patterns found in the professional lexis of three sample European languages from the perspective of such disciplines as philosophy and linguistic history. In the first part of the article authors reflect on the key traceable characteristic features of European identity forms: a closed form of identity, an open form of identity and a destructive denial of identity as a transition device from one form into another. On the basis of the linguistic survey of historical experiences as traced in British, Lithuanian and Russian legal language vocabulary formation, it is concluded that changes in legal languages are reflective of social experiences and may be viewed as identity forming mechanisms.
\end{abstract}

Key words: fusion of horizons, social identity, European identity, general vocabulary, language for special purposes, borrowings

\section{INTRODUCTION}

Globalization leads to integration of all societies, nations and cultures into an everexpanding social fabric, structurally united by industrial and communicative technologies. At the same time, it is imperative for nations to find a way of constructive coexistence. This entails fundamental research on a human social identity, which would allow to reveal both the emerging problems of coexistence and the possibilities of their solutions coded in human thought and its expression. This article will outline certain tendencies of emerging European identity that can be related to human self-actualisation through language. Ways of experiencing identity, will undoubtedly determine the future configuration of the world. In order to exemplify the parallel development of national identity and certain language corpus development three languages - the British, the Lithuanian and the Russian were broadly considered. These three cases can successfully represent various identity tendencies that throughout history intertwined with each other in each nation, but ultimately allowed one of them to dominate. This dynamics is well reflected in the language - in lexis and semantics, and in particular, in the formation of the general vocabulary and of the terminology of special areas.

The study presented here is conceived as an interdisciplinary study, the aim of which is to reflect on the social identity processes and reveal the main tendencies of emerging of 
the European identity and their expressions in the lexis of languages from the perspective of philosophical and linguistic approaches.

The objectives of the research are:

(1) to reflect on the modes of social identity and identify their main features;

(2) to establish the fundamental tendencies in the development of the European identity and to exemplify them systematically in certain societies (the British, the Lithuanian and the Russian);

(3) to overview from the historical perspective the general and the special lexis (terminology) of the English, the Lithuanian and the Russian languages and the mechanisms of identity actualisation through language.

The methods applied in the research are hermeneutics, review of literature, comparative analysis and close textual analysis.

\section{FUSION OF HORIZONS}

The research deals with the phenomenon of fusion of horizons as called by Gadamer (1960:383). The human identity develops dynamically, it is a continuous process during which the alien is absorbed into the familiar. In this respect, the fundamental law of logic, which declares that the identical is equal only to itself, ceases to have effect. The above law of logics of identity holds true on the abstract intellectual level where it plays a normative role. However, in the real life of a person, a nation, a culture, or a civilization anything that could be termed pure identity, or anything of pure familiarity without a permanent injection of the alien could not be found. Tensions appearing from the interrelation of abstract logic and real life, play an important role in reflection on the issue of human identity, with regard to both individual and social identity. These tensions generate certain tendencies in self-perception according to which an individual and the whole society interpret and develop their own identity.

What happens when horizons fuse? When the unknown, the new, the alien starts penetrating into what I consider to be the familiar? Formal logic plays its role here: the identity principle dictated by it forces set limits between the one who I am and the one who the other is, and at the same time implies certain resistance against the other's penetration into my own limits, my own horizon. This explains why Lévi-Strauss, when talking about cultural interactions, emphasized that any usage of the concept of identity starts with criticism of this concept (Lévi-Strauss 1983:331). The nature of criticism and the approach to the resistance against the other determins self-perception of identity and the form of its dynamics.

Before distinguishing the main tendencies of the dynamics of human identity, which shape the nature of language development as well as language politics, it should be noted that identity formation involves not only relationship with another culture or nation, but, on a broader scale, the relationship with the reality itself, existence of here and now, in the closest surroundings or even within oneself. Self-perception of human identity depends on the individual's reaction to any novelty, to something that one was not aware of before, but it actually existed. Though transition of a concept from the individual level of internalisation to the social cumulative level of acceptance requires a separate detailed research, it is safe to state that on a level of tendency delineation, both the individual and the human society are affected in a similar fashion. 


\subsection{Three tendencies}

The degree of resistance against otherness determines the nature of identity, which crystalizes into three tendencies. Here we mean tendencies and not clearly-cut classification groups, as the degree of resistance is absolutely individual and it would be impossible to attribute multitude of individuals who appear in-between borderlines to any classification group. The division which is proposed here reflects the dynamic forms, or to be more precise, directions of human and social experience of identity.

Resistance against otherness can be strong enough to determine the tendency towards a closed form of identity experience, usually referred to as 'essentialism', where identity is perceived as a finite substance which acquires absolute value. Cultural, national, religious and language expressions of this substance have gained a canonical status; therefore, every alteration of these expressions is treated as a threat to the identity itself. This direction leads to the formation of a monologic consciousness (Aleksandravičius 2016) which considers any dialogue with a different identity to be worthless. In extreme cases, such dialogue is regarded as dangerous and, therefore, should be avoided and forbidden. For representatives of a monologic consciousness, relationship with another identity means approaching a boundary which cannot be crossed. In extreme cases, such encounter induces the need to destroy another identity so that it ceases to pose a threat. A multitude of phenomena of the modern world express this particular form of experiencing identity, which determines the conflictual nature of the relationship between nations and civilizations, once predicted by S. P. Huntington (1996). In philosophy one of the most profound anthropological explanations of this tendency was offered by H. Bergson with reference to a closed society (Bergson 1932). Following Bergson's terminology, this type of experiencing identity is referred to as a closed identity. However, it is necessary to emphasize a fictitious nature of this closedness. Closedness of consciousness is only an illusionary impulse of mind to consider identity as a canonical and static data, disregarding the fact that in real life thousands of influences have altered and are altering it. Identity closed within itself is always only a delayed and an artificial construct (Mattéi 2007:16). Experience of identity is a degree of reality awareness. In languages this sort of behaviour is known as protection of core-vocabulary and is often reinforced by institutional supervision.

The greater the awareness of reality is, the lesser the resistance against the otherness becomes. The other is perceived as an integral part of one's own identity, as an engine of its natural development, maturation and vitality. Perception of the dynamics of human existence reveals the complex structure of identity, defined by P. Ricoeur as oneself as another, which constitutes the title of one of his major works. Perception of oneself as another suggests from the outset that the selfhood of oneself implies otherness to such an intimate degree that one cannot be thought of without other, that, instead, one passes into the other (Ricoeur 1992:3). Such approach introduces a dialogic consciousness in the cultural, political or lingual life of a human being (Aleksandravičius 2016). This dialogic consciousness functions as an active aspiration to cognize the other identity by integrating it, at least, partially, into the own identity in a way that none of the identities suffer a loss, but, on the contrary, become richer and more mature. It is an open identity functioning according to the dynamics of the open narrative, which constantly adjusts and re-creates itself. The narrative of a human being, a nation or a religion changes concurrently with the constantly renewing integration of theretofore-unknown world or 
the other horizon, which presupposes certain universal ethical requirements (Ricoeur 1992). L. Ferry (1996), who developed Ricoeur's conception of narrative identity, envisages two more aspects of formation of authentic identity - argumentative and reconstructive. During the process of 'argumentation', a person cognizes, assesses, verifies and takes decisions about another identity, which is followed by reconstruction of one's own identity, own narrative, taking into consideration cognition and recognition of the other and assuming new responsibility both for oneself and for the other. However, as D. Mattéi indicates, these distinctions are only new phraseological formulations of what the European tradition of philosophy and religion explicitly emphasized from Plato and Saint Paul to Montaigne, Rousseasu and Hegel. The self-identifying look becomes selfperception only when it meets the self-identifying look of the other. Crossing of two looks reveals the identity of each of them, which is recognizable in the looks on each other. Whatever one's culture is, one cannot perceive oneself otherwise than through the look of the other (Mattéi 2007:19). Maturity of one's own identity depends on one's openness to a different identity. Linguistically we may compare this process to the status of borrowings in the vocabulary of the language and the opening of the identity.

Nevertheless, openness to the otherness may reach the ultimate form and as such deny concern about one's own identity, thus forming an antipode to essentialism. This tendency is traced in Europe, which has assumed responsibility for the flaws and crimes of the European civilization, the lowest points in such history being colonization, two world wars and the Holocaust. Reasons for the crimes lie namely in the essentialist identity conception, which should facilitate the tendency towards the open identity presented above. However, the post-war Europe deviated from this conception to certain radicalism. Instead of fostering the ethically purified own identity emerging from the resumed respect for the Other, there were attempts to deny the identity principle itself: any identity inevitably leads to closedness and, therefore, to a militant crime. The constant state of identity deconstruction is an indispensable condition for authentic ethics, which may create peaceful coexistence of people and nations. In this article, we will not deal with the complicated question of how deconstruction should proceed. We should note that it often acquires a quite fierce form of destruction directed towards the European civilization and its identity, which is accused of the evil of the world, as the famous phrase of the writer Susan Sontag says: "The truth is that Mozart, Pascal, Boolean algebra, Shakespeare, parliamentary government, baroque churches, Newton, the emancipation of women, Kant, Marx, Balanchine ballets, et al., don't redeem what this particular civilization has wrought upon the world. The white race is the cancer of human history..." (Sontag 1967:57). The postwar European thinking was characterised by extreme self-criticism, which, according to Manent (2006), is expressed in all areas of life, starting with art and ending with politics, as openness to the Other, which due to its specificity makes us mention Europe only in order to deny it. Consequently, we do not have our own original existence - we do not want it, we do not want it by any means (Manent 2006:93). Whether it is this tendency, no matter how paradoxically it may sound, that does not lead to restoration of closed identity against which it was directed is questionable. Self-denial returns on the rebound to such self-determination which is directed against the Other, i.e. against what the reason to deny own identity was. Absence of resistance turns into the need for extreme resistance. That might explain the reviving nationalism in Europe which is being formed by extreme and populist conservative powers. 


\subsection{European exclusiveness}

Europe exhibits all three tendencies of identity formation. Nevertheless, the European exclusiveness in the world is created by the second tendency, which is regarded as a concept of open identity. The tendency of the open identity in Europe has been much stronger than in other parts of the world. This is usually explained by fusion of ancient Greek thinking and Judeo-Christian culture that was part of the Roman Empire in the first centuries AD. It is the Roman mentality, formed by openness towards alien, that Brague regards as the essence of the European identity, "the eccentric identity"; it was inherited by the Christian Middle Ages and later determined the most important social processes in the Europe of our times (Brague 1999).

In addition to the original Roman mentality, we need to emphasize the European concept of a human being as a person. The deepest roots of this concept lie in the biblical statement that the human being has been created in God's "image and likeness". As Housset's (2007) research shows, the Christian interpretation of human existence, referring to God as the Holy Trinity, results in not only absolutisation of human values, but also its fundamental ontological relation or, in other words, openness to the other: created in the image of the Trinity, i.e. pure Relationship, humans find themselves and their own identity only when being in an open relationship with the Other. We shall not stop at a well-known fact that in the modern times Kant established the same concept of a human being as a person, justifying its secular version on the basis of arguments of a purely rational mind. In this respect it is worthy to list the historical phenomena specific to the European tradition that lead to its dynamic and ethical identity: for us, the most important emphasis is on the fact that since ancient Greek times the European consciousness has been marked by a specific relationship with reality, which can be described as fundamental openness and which is expressed through the desire for knowledge, tolerance, dialogue, creativity, dynamics, criticality, rationality, democracy and freedom - the values which have connotations of both volatility and ethics. It is in this anthropological structure of openness to the other while maturing oneself that the universal dimension of Europeanness should be discerned, whether we interpret the rationality of the categories as Husserl (1954) did, or whether we interpret it as a vital intuitive flair, which leads to realization of open society in the world, according to Bergson (1932). Europe's mission in the world is to spread openness to any civilization and culture.

This is a difficult mission as openness has always been resisted due to the anthropological processes already discussed above. Europe has carried out its mission with difficulty not only throughout the world, but also within its own borders. Although the third identity concept, which tends to renounce the own self in the name of the other, appeared in Europe only sporadically, we can assert that from the ancient Greek times the historical European tradition has been penetrated by the struggle between the tendency of the open identity and the tendency of isolation. This struggle can be illustrated by numerous historical facts, which confirm that in Western Europe the tendency towards openness has regularly overcome the closed identity, while in Eastern Europe, by contrast, the closed identity has dominated, despite notable breakthroughs towards openness. To further the reflection in perspective of the linguistic expression of identity, the focus will be on an example of three countries - Great Britain, Russia and Lithuania. 
At first glance it might seem that in the UK tendencies towards isolation have been stronger than in mainland Europe. The British have always tended to emphasize the status of Britain as an island, thus a separate area, as well as their cultural distinctiveness from the rest of Europe (and the world), often viewing it a synonym for superiority. This position has led to a constant political trend of Great Britain (before that - England) to turn away from Europe, beginning with separation of the Church of England from the Roman Catholic Church in the sixteenth century, and ending with the recent referendum which approves separation of the United Kingdom from the European Union and has quite a symbolic name - Brexit. Instead of cooperation with Europe, Great Britain seems to have chosen expansion in various directions all over the world and, despite the undoubted scientific progress which has been facilitated in many parts of the world, it has been marked by a strictly reserved attitude towards the peoples and cultures they encountered - this is what we refer to as colonialism. There is no denial of the obvious tendencies in the British society towards isolation. However, a closer look at the British mentality, the way of preserving their identity, calls for the revision of the general conclusion that the main form of British existence is closedness. On the contrary, it is in England, as early as in the Middle Ages, that we find the first rudiments of modern democracy, which coincide with publication of the Magna Charta Libertatum in 1215 the first constitutional act in Europe. We will not exaggerate by saying that it is the concept of freedom that has become the cornerstone of the organization of the British society in the Modern Ages and in our times. Locke's liberalism, the doctrine of human rights, tolerance, and multiculturalism, despite the inevitable xenophobic trends, reveals the fundamental openness of the British identity consciousness. Its historical dominance with respect to isolation is most vividly confirmed by cultural exchange, which has taken place at all times with Europe and the rest of the world despite the geopolitical realities of life. Perhaps the most impressive example thereof is provided in the time of Queen Elizabeth I: despite the prevailing climate of political tension and hatred between the English and the Spanish, the English admired Spanish literature, translated it into English and distributed it throughout the expanding empire. Modern English language, as we know, is based on amalgams of Germanic and Latin elements. There is no doubt that in terms of 'openness' and 'isolation', which are used in the sense we have presented, the British society is essentially an open society despite trends towards isolation.

Diametrically different conclusions should be drawn while considering the way the Russian society has preserved its identity. After liberation from the terrible effects of the Mongol oppression in the $15^{\text {th }}$ century, formation of the Russian society and the state was influenced by both identity tendencies - towards isolation and openness. The conflict is best represented by two different ideologies, i.e. fight between Slavophiles and Zapadniks, which started since the time of Peter I and is still relevant today. Zapadniks, who during certain historical eras belonged to the political and cultural elite, strived to open Russia to the Western cultural and political tradition, reforming it in accordance with the European standard of living. The $18^{\text {th }}$ and $19^{\text {th }}$ centuries Russian public education, i.e. higher education, was fully open to the ideas of Western European Enlightenment philosophy, whereas art adopted essentially European expression. Wellknown facts demonstrating openness are the architecture of Winter Palace in St. Petersburg and the extensive use of the French language among the Russian aristocracy. However, reforms of the beginning of the $20^{\text {th }}$ century by the Russian Prime Minister Stolypin can be considered the last example of Zapadniks' activity in Russia. Slavophiles, 
led by Orthodox Church (however, it should be noted that Russia has never adopted the principle of separation of political and religious powers in reality, so the Orthodox Church has always been associated with the political will), have always strongly opposed any European influence, demonised it and called for holy wars against it, at least within the Russian society, as the biggest threat to the Russian identity. Sacralisation of the Russian identity, while assuming other identities as an expression of human degradation, has formed an extremely strong tendency in the self-perception of the Russian society. Despite the undeniable attachment of a certain segment of the public to the values of openness, which was resembled in a symbol of resistance during the Soviet times, Andrei Sakharov, the identity experience in accordance with the isolated way of living in this society dominated both in the modern and in our times. Causes of the recent military aggression in Ukraine are not only geo-political; it was drawn on a pseudo-religious doctrine based on revenge moods, promoted by Dugin and openly supporting intercivilization military conflict as a necessary measure to protect the world and promote the 'sacredness of Russia'.

The Lithuanian society has retained a strong sense of national identity, in spite of the processes of Germanisation, Polonisation and Russification during the modern times. These processes seem to further emphasize attempts of the Lithuanians to revive ties with the traditional ethnic elements of their own identity - Lithuanians are often proud of the fact that the country was the last nation to be christened in Europe (the official date christening is 1387). However, Christianity in Lithuania has formed a perfect symbiosis with the national identity. These preliminary observations on the Lithuanian identity alone lead to the conclusion about its open nature. In addition, Lithuania has always been regarded as a cultural and political mediator between Western Europe and Russia. The most prominent Lithuanian philosophers of the 20th century, S. Šalkauskis, A. Maceina, have developed the theory of this mediation, which does not lose its relevance to the present day (Šalkauskis 1919, Maceina 2007). The political mission of such mediation was realized in times of the Grand Duchy of Lithuania, which fell in 1795, whereas the cultural mission continues today, viewing the Lithuanian identity as a point of Western and Eastern symbiosis manifested both in art and the Lithuanian mentality. However, a takeover of different influences results in a takeover of tendencies of the identity experience. Openness of Western Europe is viewed by both political and cultural elite of the nation as an absolute value and the target, while the Russian isolation forms have undoubtedly affected the real Lithuanian identity status - we can easily identify this effect as early as in the $19^{\text {th }}$ century, let alone the times of the Soviet Union occupation in the $20^{\text {th }}$ century. While competing with each other, tendencies to open and closed forms of identity experience currently maintain a certain balance. Openness, powered by the historical reality and officially formulated future goals, in the Lithuanian society often confronts with reconstruction of the static identity, which is in line with the national goals of ideological and propagandist nature.

\subsection{Lingual expressions of identity}

The further research here is based on the assertion that human experiences of reality and human languages are coextensive and this is manifested not only in semantics, but also in formation of vocabulary - the process of formation of lexical items of general vocabulary and special vocabulary (terminology). Hence, the above-mentioned 
tendencies of formation of identity are reflected also in national languages. The argument is that the nature of identity constitutes particular principles for the formation of vocabulary, which will be revealed relying on the contrastive analysis of the sources of formation of the vocabulary of the national languages of three countries - Great Britain, Russia and Lithuania. The focus is to identify the influences of other languages on English, Lithuanian and Russian general and special lexis, i.e. terms used in legal acts of a constitutional nature in Great Britain, Lithuania and Russia measured against the historical background of the development of the English, Lithuanian and Russian languages.

The relations between the citizens and the state, the system of state government, its structure, institutions, etc., are morphologically regulated by the Constitution and the Constitutional Law. Therefore, the language of constitutional acts includes a great variety of terminology of different areas of social life; and it serves as a plausible field for the analysis of the development of special vocabulary of the languages under survey.

Open type of the British identity may be traced as a pattern in the history of development of the English vocabulary. Starting with the Anglo-Saxon words, English gave way to the borrowings from various other languages. David Crystal called the English language an "insatiable borrower". And Collins dictionary shows the recent growth of this phenomenon in the English language through the increase of the usage of the term.

Borrowings in languages may be happening because of social and attitudinal factors (prestige of the donor language, puristic attitudes) and because of grammatical factors, to quote Martin Haspelmath (2009). Borrowings may be classified into cultural and core vocabulary borrowings. Fasold (1984:180) states that mechanism of borrowing is related to cultural fusion when a new concept is introduced to a culture, new words are required. The language embraces a term and experience from the other culture and this phenomenon is called 'borrowing'.

The sketch of borrowing histories of English, Lithuanian and Russian legal terminology below does not analyse the character of legal borrowings in the English, Lithuanian or Russian languages but rather traces the tendency to adopt the alien realias in their own languages and establish their own identities in the legal linguistic area. Many researchers worldwide counted that Modern English vocabulary includes borrowings from more than 120 languages (Jackson and Zé Amvela 2012:39, Šeškauskienè 2013:302). Historically, e.g. in Old English period (450-1066), borrowings were not that common. Almost all of Old English vocabulary was of closed, insular origin, except for about 3\% of borrowings (Jackson and Zé Amvela 2012:29, McIntyre 2010:132). Some borrowings (namely toponyms and hydronyms) came from the Celtic languages with whom Anglo-Saxons came into contact when they invaded the British Isles in the $4^{\text {th }}-6^{\text {th }}$ centuries. Later, in the $8^{\text {th }}$ to $11^{\text {th }}$ centuries, a set of borrowings came from Old Norse as a result of Viking invasions. These were toponyms, anthroponyms and general words. The process of borrowing became much more extensive in the Middle English period (10661500) when England was invaded by Normans who brought a great impact of French and Latin on various areas of the English vocabulary (Jackson and Zé Amvela 2012:37-38, 42-43). Since this period borrowing has been a productive means of enriching vocabulary ever since. English has acquired borrowings from Greek, Italian, Spanish, Portuguese, German, Dutch and other languages (Šeškauskienė 2013:302-307). The amount of borrowings in Modern English is particularly high reaching more than 70\%. As McIntyre 
claims "the rich vocabulary of English is a result of the extent to which it has borrowed from other languages during the course of its history" (McIntyre 2010:91). The proportion of borrowings in English depends to a large extent on the type and the stylistic level of a text. Jackson claims that "formal style and specialized language use a greater proportion of foreign loans than does everyday conversation" (Jackson and Zé Amvela 2012:53-54). The most frequently used words of the everyday language are usually of native origin, while special vocabulary (terminology) is mostly borrowed.

The influence of other languages on English is especially vivid in the area of law, though the legal system itself has retained a rather closed, non-continental status. The development of the English legal terminology was greatly influenced by French and Latin in particular. In the Middle Ages, French was the main language spoken in courts of England, while legal documents were drawn up in both French and Latin. The reason why French and Latin were extensively used in the area of law instead of English might be due to "the urge to have a secret language and to preserve a professional monopoly" and thus to set the legal profession apart from the rest of the society (Maley 1994). Only at the end of the $15^{\text {th }}$ century, legal acts were printed in English. Lawyers started using English as the official language only in the $17^{\text {th }}$ century, and it gradually replaced the use of legal French and legal Latin (Jackson and Zé Amvela 2012:44-45, Maley 1994). Because English was in close contacts with French and Latin, the formation of the English legal terminology and its characteristic features were strongly influenced by the two. Historically, the concept of the legal language as the language of belonging to a closed social group was gradually internalised by the common, general English language users' group. The language change is rather exemplary of the internalising of an alien language expressions and exposing the openness tendency of the identity of the culture.

The analysis of English terms used in constitutional acts confirms the tendency of the British identity perception as the open type identity. The research conducted by Mockiene (2017) on formation of terms in constitutional legal acts in English, Lithuanian and Russian reveals that the majority of English terms of constitutional law are borrowings: $83 \%$ of oneword terms are from external sources and 3\% of terms are formed on the basis of combining morphemes of native and foreign origin. The majority of borrowed terms are of Romance (predominantly from Latin and French) and Greek origin, e.g. act (< Latin actus), amendment ( $<$ French amendement $<$ amender), scheme $(<$ Latin schēma $<$ Greek $\sigma \chi \tilde{\eta} \mu \alpha)$. In most cases, they came into English directly, in some cases through intermediary languages, e.g. authority ( $<$ French auctorité $<$ Latin auctōritāt-, auctōritās), throne ( $<$ Old French trone $<$ Latin thronus < Greek thronos). Examples of hybrids are by-election (a native prefix by- + a base of Latin origin, which came into English through French election), membership (member + a native suffix -ship). The composition of the English constitutional vocabulary shows that the English language has been undergoing a process of opening to the wide spectrum of other languages through multiple borrowings to the special vocabulary of legal life. Such society viewed from the language identity prism appears to possess an open type of identity.

The Russian social identity could be characterised by both tendencies, i.e. towards isolation, closedness and towards openness. However, the former tendency prevails in the history of Russia, which is also reflected in the language development. Although Russia did not experience such numerous invasions by foreign nations as Britain, until the $18^{\text {th }}$ century it was bilingual: the folk Russian language was used alongside the Old Church Slavonic. The use of these two languages depended on the particular sphere of 
communication: the folk Russian language was reserved for spoken communication; whereas the language of written communication was the Old Church Slavonic. The Old Church Slavonic was primarily used in judicial matters, prosecution, trial, for recording testimony and even to write scientific works (Superanskaja et al. 2012:171-172). Although the duality of languages separated group identities within one country, for almost a thousand years, Old Slavonic was an open medium of uniting the Slavic nations in such important areas of life as religion, science and literature. Some traces of the Old Church Slavonic can be still seen in science as it served as a universal means of term formation and was characterised by its own models of term formation and lexical basis (Superanskaja et al. 2005:112-134). From the onset of the $18^{\text {th }}$ century a number of borrowings entered Russian from Western European languages. The active process of borrowings was related to a growing number of new terms used in spheres of state and government matters, politics, diplomacy, law, administration and justice. Another set of borrowings was introduced in the area of the navy military and science, finances, education, religion and culture. Borrowings which came into the Russian starting with the $18^{\text {th }}$ century, enriched the language not only by lexical items as such, with a number of elements of Romance and Germanic origin, but also by entire terminological systems. The impact of Western European languages on Russian is also proven by the fact that in the $18^{\text {th }}$ century scientific papers of the Russian Academy of Science were written in Latin, in the $19^{\text {th }}$ century they were published in French, whereas some papers were also drafted in German. Scientific works were published not only in foreign languages, but also in Russian. There are quite a lot of borrowings of Latin origin, which entered Russian through some intermediary languages, such as French or German. They are primarily related to areas of science and culture. Besides, it should be noted that most of such borrowings were adapted in Russian in the form closer to their Latin original, than the form they were used in the intermediary language. In the $19^{\text {th }}$ and $20^{\text {th }}$ century, numerous borrowings entered Russian due to globalization processes, predominantly from Western languages, such as English (Superanskaja et al. 2012:171-192).

Despite the active disposition towards adding borrowings to the native language, the number of foreign words in Russian legal terminology is not high. The analysis of Russian terms used in constitutional law reveals that only $22 \%$ of terms one-word terms come from the external sources and $3 \%$ of terms are hybrids formed on the basis of combining suffixes of native origin and bases of foreign origin (Mockiene 2016). Most of them are of Latin origin and just a few are of Greek origin and entered Russian through or under the influence of intermediary languages, predominantly Western European languages, such as French, German, and Polish, e.g. референдум 'referendum' ( $<$ Latin referendum), суверенитет 'sovereignty' (through German Souveränität $<$ French souverainité, based on Latin superus), парламент 'parliament' (through German Parlament, English parliament, or French parlement, based on French parler), религия 'religion' (through Polish religia < Latin religiō or directly from Latin), амнистия 'amnesty' (through Polish amnestia or French amnistie < Greek amnēstia or directly from Greek), политика 'policy' (through German Politik or French politique < Greek politikē). Some terms of Romance origin were formed in French and came into Russian either through intermediary languages or directly: бюджет 'budget' (< French budget < Old French bougette). It is noteworthy that all of them are international words. The composition of the Russian constitutional vocabulary shows that the Russian legal language is quite isolated. Russian developers of the legal terminology strive to preserve 
the native Russian vocabulary, thus the social identity type in this language area is rather a closed identity, not inclined to introduce the terminology covering foreign social experiences.

The Lithuanian language is also characterised by the tendency towards isolation which is evident in the development of vocabulary of the Standard Lithuanian language. Despite its turbulent history and numerous invasions, Lithuania has retained a strong sense of the national identity. Although the Lithuanian society underwent the process of Polonisation and Russification, Germanisation, the Lithuanian language contains only 1.5 $\%$ of Slavic borrowings and $0.5 \%$ of Germanic borrowings. Other languages, with whom Lithuanian had direct or indirect contacts (Yiddish, Latvian, Baltic Finns, etc.) had very little impact on the Lithuanian vocabulary, just several words were borrowed from them (Jakaitienè 2009:227-231).

It is presumed that the first Slavic borrowings entered Lithuanian in $9^{\text {th }}-11^{\text {th }}$ centuries from East Slavic dialects. Later, borrowings came from the Chancery Slavonic (Ruthenian Language), which was the official written language of the Grand Duchy of Lithuania. In the $16^{\text {th }}-18^{\text {th }}$ century, when Lithuania was in a commonwealth (federation) with Poland (1569 to 1795), the Lithuanian language was under a strong influence of Polish which was extensively used by the Lithuanian nobility and indicated their belonging to the higher class in society. Meanwhile, Lithuanian was used mainly by peasants as a spoken language. The influence of Polish was vivid not only in extensive borrowings, but also in orthography: several Polish letters and digraphs were introduced into the written language (Subačius 2002:9). When Lithuania became part of the Russian Empire (1795 to 1914), official language was Russian. Lithuanian was forbidden for printing and speaking in public. The phenomenon of book smugglers, which was recognized by UNESCO as unique, was created to illegally import Lithuanian books and press from Germany. During this period, Russian borrowings entered Lithuanian (Jakaitienè 2009:229-230).

Lithuania Minor (Western Lithuanian territories) was a part of Prussia since $18^{\text {th }}$ century and was under the influence of German culture. Numerous German borrowings entered Lithuanian dialects spoken in Lithuania Minor. However, despite Germanization of this region, it became the cradle of the Lithuanian written language. In the $16^{\text {th }}$ century, the first Lithuanian book (The Simple Words of Catechism by Martynas Mažvydas) was printed in Lithuania Minor; it was followed by the first Lithuanian translation of the Bible, the first Lithuanian grammar, German-Lithuanian, Lithuanian-German dictionaries, etc. (Subačius 2002:8).

Although the contacts with Slavic and German languages were very strong, neither of the languages contributed to the vocabulary basis of the Standard Lithuanian which became the official language of the state after 1918 when Lithuania restored its independence. Big efforts were made to purify the language and to create Lithuanian neologisms to name various concepts which were identified as Slavic borrowings. Most of the old Slavic and Germanic borrowings, which were preserved, were fully assimilated in the language. The Restoration of Independence in 1918 marks also the beginning of the development of the legal Lithuanian language (Maksimaitis 2007). Before that, legal documents in Lithuania were drawn up in Latin or Slavic languages (Umbrasas 2010:16). In 1918-1940, when Lithuania enjoyed independence, legal acts were drafted in Lithuanian and the state paid considerable attention to development of legal terminology (Umbrasas 2010:265). It should be noted that although Slavic languages had significantly 
affected the Lithuanian legal language at the onset of its development, borrowings from these languages were gradually replaced by equivalents of Lithuanian origin and terms of Romance and Greek origin, which came into the language either directly or through intermediary languages. According to Maksimaitis, the interwar period, a strong background for the development of the modern Lithuanian legal terminology was formed (Maksimaitis 2007). During 1945-1990, when Lithuania was a part of the Soviet Union, the Lithuanian language was again strongly influenced by Russian; legal terminology was formed and managed according to Soviet legal standards. Since the restoration of Independence in 1991, the Russian influence was replaced by that of the Western culture, mainly the English language. However, Standard Lithuanian is purposefully preserved by the National Commission for the Lithuanian Language, which is responsible for monitoring the use of the language.

The tendency towards preserving a strong sense of national identity is also evident in the area of the Lithuanian constitutional language. The analysis of Lithuanian terms used in constitutional law reveals that, similar to the Russian legal terminology, only $22 \%$ of terms one-word terms come from the external sources and $2 \%$ of terms are hybrids formed on the basis of combining suffixes of native origin and bases of foreign origin (Mockiene 2016). The main sources of borrowed terms are Latin and Greek; the terms entered Lithuanian either directly or through Western European languages (such as French, German, English, Italian), e.g. aktas 'act' ( $<$ Latin actus), finansai 'finances' (< French finances $<$ Latin Financia), biurokratismas ‘bureaucratism' $(<$ French bureaucrate $<$ French bureau + Greek kratos), autonomija 'autonomy' ( $<$ Greek autonomia), policija 'police' (through German Polizei < Greek politeia). Examples of hybrids are suverenumas 'sovereignty' $<$ an adjective suverenus 'sovereign' $(<$ a base of French origin souverain) + Lith. suffix - umas, finansav-imas 'financing' $<$ a verb finansuoti 'to finance' ( $<$ a base of French origin financer) + Lith. suffix -imas. Thus, the composition of the constitutional Lithuanian vocabulary confirms the Lithuanian closedness, which is seen as an indispensable means to preserve the language.

\section{CONCLUSION}

Historically, the identity of a whole society was always shaped by adopting otherness into what had already been one's own. In ontological sense, identity can exist only as a result of fusion of horizons, to use Gadamer's term. The dialectics of open and closed identity is the best conceptual instrument for analysing the dynamics of social and human identity in its historical transition, keeping in mind transitions to extremes: the open identity can become 'hollow' and begin to deny itself, whereas the closed identity can expand offensively and deny the other.

Examples of the historical development of the borrowings in the legal terminology of the three nations (the British, the Lithuanian and the Russian) illustrate this fundamental dynamics, which captures cultural, political, economic and other social expressions of identity. Formation of general vocabulary is mostly based on unconscious processes of vocabulary development, while terminology is a result of conscious work on designation of concepts. Both the conscious and unconscious processes, reflect the same tendencies towards openness and closedness of national languages reflecting social changes in these countries. 
The process of borrowing into languages is a mechanism of fusing identities. Historical cut of selected European languages (English, Lithuanian, Russian) shows that composition of the general and special vocabulary allows to draw parallels to the social and political status of the country and the social powers of the country. Global changes appear to go along with the languages and identities expressed by these languages that are historically inclined to be open to language borrowings. Borrowings dominate in both general and especially legal English (constitutional acts), where they, for example, constitute four fifths of one-word terms. In contrast, the composition of the Standard Russian and Standard Lithuanian vocabulary shows that these two languages are quite isolated, i.e. manifest closed national identity type. Despite numerous contacts with other nations and languages, borrowings do not prevail in Russian and Lithuanian. Although there is about one fifth of borrowed one-word terms in constitutional law of Russia and Lithuania, most of them are international words of Latin and Greek origin. Developers of the Russian and Lithuanian legal terminology give clear priority to internal sources of term-formation, thus demonstrating the conscious efforts to restrict the openness towards other languages, which is seen as an indispensable means to preserve the language.

\section{REFERENCES}

Aleksandravičius, Povilas. 2016. 'The need for dialogic consciousness in postmodern politic society'. Philosophy, sociology 27, 1: 14-22.

Bergson, Henry. 1932. Les deux sources de la morale et de la religion. Paris: PUF.

Brague, Rémi. 1999. Europe, la voie romaine. Paris: Gallimard.

Crystal, D. 2013. On Langugae Change. Available from: https://www.englishandmedia. co.uk/assets/uploads/documents/emag_61_taster.pdf.

Crystal, D. 2013. Loan word. Available from: http://www.davidcrystal.com/?id=2810.

Crystal, D. 2003. English as a global language. Cambridge: Cambridge University Press.

Fasold, R. 1984. The sociolinguistics of society 1. New York: Basil Blackwell Ltd.

Ferry, Jean-Marc. 1996. L'Éthique reconstructive. Paris: Cerf.

Gadamer, Hans-Georg. 1960. Wahrheit und Methode. Tübingen: J. C. B. Mohr.

Haspelmath, M. 2009. Lexical borrowing: Concepts and issues. Available from: https://www.researchgate.net/publication/279973916_Lexical_borrowing_concepts_a nd_issues.

Housset, Emmanuel. 2007. La vocation de la personne. Paris: PUF.

Huntington, Samuel Phillips. 1996. The Clash of Civilizations and the Remarking of World Order. New York: Simon and Schuster.

Husserl, Edmund. 1954. Die Krisis der europäischen Wissenschaften und die transzendentale Phänomenologie. La Haye: Nijhoff.

Jackson, Howard and Etienne Zé Amvela. 2012. Words, Meaning and Vocabulary: An Introduction to Modern English Lexicology (2nd ed.). London: Continuum.

Jakaitienè, Evalda. 2009. Leksikologija. Vilnius: Vilniaus universiteto leidykla.

Khrisat, A. Majiduddin, S. M. 2014. 'Language's Borrowings: The Role of the Borrowed and Arabized Words in Enriching Arabic Language'. American Journal of Humanities and Social Sciences. World Scholars, LLC, USA.

Linguistic borrowings. Collins Dictionary Online. Available from:

https://www.collinsdictionary.com/dictionary/english/linguistic-borrowing. 
Lévi-Strauss, Claude. 1983. L'Identité. Paris: PUF.

Maceina, Antanas. 2007. Raštai. Vol. XIII. Vilnius: Margi raštai.

Maksimaitis, Mindaugas. 2007. 'Prie lietuviškos teisès kalbos ištakų'. Jurisprudencija 95, 5, 7-13.

Maley, Yon. 1994. 'The Language of the Law'. In John Gibbons, ed. Language and the Law, 11-50. London: Longman.

Manent, Pierre. 2006. La Raison des nations. Réflexions sur la démocratie en Europe. Paris: Gallimard.

Mattéi, Jean-François. 2007. Le regard vide. Essai sur l'épuisement de la culture européenne. Paris: Flammarion.

McIntyre, Dan. 2010. History of English: A resource book for students (2nd ed.). London: Routledge, Taylor \& Francis Group.

Mockienè, Liudmila. 2016. Formation of terminology of constitutional law in English, Lithuanian and Russian / Konstitucinès teisès terminu daryba anglu, lietuviu ir rusu kalbose: doctoral thesis: humanities, philology (04 H). Vilnius: Vitae Litera.

Ricoeur, Paul. 1992. Oneself as Another. Translated by K. Blamey. Chicago: University of Chicago Press.

Sontag, Susan. 1967. 'What's Happening in America?' Partisan Review 34, 1: 57-58.

Salkauskis, Stasys. 1919. Sur les confins de deux mondes: essai synthétique sur le problème de la civilisation nationale en Lituanie. Genève: Atar.

Subačius, Giedrius. 2002. The Lithuanian Language: Traditions and Trends. Vilnius: Inter Se.

Superanskaja, Aleksandra V., Podol'skaja, Natalija V., \& Vasil'eva, Natalija V. 2005. Obščaja terminologija: Terminologičeskaja dejatel'nost'. Moskva: URSS Jeditorial.

Šeškauskienè, Inesa. 2013. Ways with Words: Insights into the English Lexicon and some Cross-Linguistic Aspects of Study. Vilnius: Vilnius University Publishing House.

Umbrasas, Alvydas. 2010. Lietuviu teisès terminija 1918-1940 metais: Pagrindiniu kodeksu terminai. Vilnius: Lietuvių kalbos institutas 